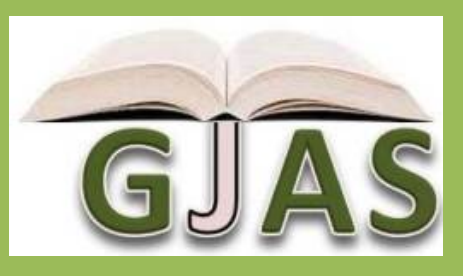

\title{
Evaluation of Livestock- Crop Enterprise Diversity Associated with Shift from Pastoral to Agro-Pastoral Farming Systems in Transmara West District of Narok County- Kenya
}

\section{Magembe E.M. ${ }^{1 *}$, Bebe B.O. ${ }^{2}$, Lagat J.K. ${ }^{3}$}

${ }^{1}$ Department of Agriculture, Meru University of Science and Technology P.O BOX, 972-60200, Meru.

${ }^{2}$ Department of Animal Production, Egerton University, Box 536, Njoro, Kenya.

${ }^{3}$ Department of Agricultural Economics and Business Management, Egerton University, Box 536, Njoro, Kenya.

ARTICLE INFO

Article No.: 020514093

DOI: 10.15580/GJAS.2014.3.020514093

Submitted: 05/02/2014

Accepted: 16/04/2014

Published: 17/04/2014

${ }^{*}$ Corresponding Author

Magembe E.M.

E-mail: esymachana@

yahoo.com

Phone: +254725719013

Keywords:

Maasai community, decision,

livelihoods, shift, livestock and

crop diversities
The Kenyan Government in partnership with the private sector has set up cooperative societies for marketing livestock and livestock products in TransMara west district of Narok County. These co-operatives are supposed to trigger extensive expansion in livestock production. Despite perceived steady incomes, high turnover and ready market for livestock associated with existence of cooperatives in the area, the pastoral Maasai community is shifting from pastoralism to agro-pastoralism. This community is strongly traditional with much cultural and economic attachment to livestock. The shift in livelihoods could be following a rational and economic decision with effects on the diversity of livestock and crops but empirical evidence is lacking to ascertain this assumption. Evaluating livestock and crop enterprise diversities associated with the shift may explain the rationale of observed behavior and inform development strategies for such areas. Specific objective of the study was to compare pastoral and agropastoral based livelihoods for livestock and crop enterprise diversities of the farming systems associated with the shift. Data were collected from a sample of 130 households through interview schedule. The diversity of crops and livestock was based on Shannon index. The findings indicated that the diversity for crops was 0.3 units higher in agro-pastoral farming compared to pastoral farming. 


\section{INTRODUCTION}

In Kenya, almost 8 million people depend on pastoral livelihoods (Adeel and Uriel, 2005). Pastoralists own over $70 \%$ of Kenyan national livestock herd valued at over US\$ 1.55 billion (Fineline systems and Management Company, 2010). Kenyan pastoralists live in the arid and semi arid lands (ASALS) characterised by high rainfall variability and with recurring droughts which impact on rangeland productivity. In some ASALS, where rangelands receive reliable rainfall pattern which can support crop production, pastoral households have responded by introducing commercial crop production. Consequently, the response has been associated with gradual shift from pastoral livelihoods to agro-pastoral land use systems (Gumbo and Maitima, 2007; Mwang'ombe et al., 2009).

Other pastoral households in the traditional setting have developed multiple coping mechanisms to deal with drought. Such mechanisms include herd and income diversification (COMESA, 2009; Galvin, 2009, 1992). Pastoral lands have been known to maintain large indigenous herds of livestock and it is not known whether these large herds exist in agro-systems. The large indigenous herds are likely to be of increasing value in the face of climate variability (WISP, 2008; Cavatassi et al., 2006).

The Maasai community have had a long time history in pastoralism, and in Kenya they are known as an indigenous group of people who comprise of pastoralist and semi-nomadic livestock herders. The Maasai community form the second biggest group of pastoralists in Kenya. Among the pastoralists of Southern Kenya, are the Maasai of TransMara West districts, who are shifting from pastoralism to agropastoralism (Herero et al., 2006).

This kind of shift in livelihoods which is ongoing in TransMara West district among traditionally pastoral Maasai community, who have had a strong attachment to livestock keeping, may be a reflection of change from traditional dietary habits of eating meat, milk and blood to vegetables to cope with drivers of pastoral pressures, but empirical evidence is lacking to ascertain this assumption. Even though the change in their lifestyle is expected, research has shown that under conditions of good rainfall, the profitability of pastoral operations in terms of incomes alone is much more than those of crop farmers (Herero et al., 2006; Gumbo and Maitima, 2007; Mwang'ombe et al., 2009). This acts as an incentive and a framework upon which we need to understand both livestock and crop enterprise diversities in the study area.

In the district, integration of crops and livestock systems has led to competition for land resource between livestock and crops. Adding to land pressure is higher growth rates of population and in-migration to pastoral lands (Coast et al., 2001, 2006; Tangus, 2004; Akinwumi et al., 1996). In pastoral land use, land ownership remains communal, unlike in agro-pastoral land use where, land ownership is private, which may be used for ranching and crop enterprises.

In Kenya, agro-pastoral land use systems have been on increase (Gumbo and Maitima, 2007; Mwang'ombe et al., 2009), but the implication of those land use systems on livestock and crop enterprise diversities have not been well understood. Increased conversion of fertile range lands to commercial cultivation in TransMara West district has led to competition for land resource between livestock and crops. Remaining rangelands have been increasingly privatized through sub-division and allocation of rights for ranching and farming enterprises. Moreover, high rates of population growth and in-migration have added to both real and perceived pressures on pastoral lands (Coast et al., 2001, 2006; Tangus, 2004; Akinwumi et al., 1996).

Access to extensive land offering potential for grazing and water resources promote mobility in pastoral production system. Therefore, changes restricting access to these grazing resources increase pastoral vulnerability to drought and loss of livestock assets, which pose threat to sustainability of pastoral-based livelihoods (Coast et al., 2006; Mwangi, 2005). Faced with such threats, many pastoral communities have responded with diversification of livelihoods to agropastoralism (Binsbergen and Watson, 2008; Galvin, 2009; Freeman et al., 2008). The Maasai community in TransMara West district is not exceptional even though the crop and livestock diversities associated with the shift have not been well understood.

To mitigate some sustainability threats to pastoral livelihoods, the Kenyan government in partnership with the private sector promoted integration of pastoral economy into market economy (Morton and Meadows, 2000; Mochabo et al., 2006). This has been through setting up of co-operative societies in the TransMara district to open ready market for livestock and livestock products trading in order to accommodate financial and social capital. Availability of ready market could be associated with steady incomes and high turnover for pastorals, however, this development strategy has not been able to support sustainable pastoralism, evidenced by ongoing gradual shift to agropastoral based livelihoods (Morton and Meadows, 2000; Mochabo et al., 2006). The shift in livelihoods is presummed to be associated with trade-offs in diversity of crops and livestock which had to be evaluated.

There is a large body of literature on trade-offs between livelihoods and environment (Ayantunde et al., 2008; Freeman et al., 2007, 2008; Gerber et al., 2009; Herrero et al., 2006), however, these researches did not evaluate characteristic differences in diversity of crops and livestock enterprises associated with the shift from pro-conservation land use pastoral system to less conservation agro-pastoral system (Griffiths, 2007). This knowledge could inform better understanding of household decision making and trade-offs in the shift from livestock based livelihood assets to livestock-crop 
integration in a community with known strong cultural attachment to livestock. The study sought to compare pastoral and agro-pastoral based livelihoods for livestock and crop enterprise diversities of the farming systems associated with the shift.

\section{THEORETICAL AND CONCEPTUAL FRAMEWORK}

\section{Livelihood Diversification Theory}

The theory holds that people undergoing diversification alter their activities, location, social identity, aspirations and primary sources of income (Homewood et al., 2009). These separate and twinned processes do not take place in any particular sequence and more often they overlap. The theory holds for households living mainly from herding and to some extent diversifying into other alternative sources of income (Freeman et al., 2008; Arunga et al., 2009). Changing of social identity and aspirations of pastoralists, involves change of attitude to western education and perception to women roles (WIBD, 2005). On the other hand, change of pastoral activities implies limited mobility (Lesorogol, 2008; Campbell, 2000) thus catalysing intensive land usage. The theory is pegged on the fact that sedentarization occur due to push factors (pastoral exclusion in terms of prime grazing lands and watering points) and pull factors (access to education, health and social services). Moreover, poverty, loss of opportunities and means to pursue those opportunities accelerates sedentarization (Coast et al., 2006).

\section{Random Utility and Choice Theory}

This theory states that preferences are not directly observable, but can be discovered through behaviour observation. It is assumed that preferences remain unchanged as behaviour is observed. Ones preference to shift from pastoralism to agro-pastoralism cannot be observed but the behaviour associated with this shift can be observed such that, a decision maker i must choose from a set of mutually exclusive alternatives, $n=1 \ldots \ldots n$. The decision maker i obtain utility $U$ in from each choice made. Given a set of alternatives as stated above $(n=1 \ldots, n)$ a rational individual will chose an alternative that provides the highest utility. The model is constructed on the premise that the decision maker chooses the choice that maximizes utility. The random utility function is expressed below as given by Simtowe (2009);

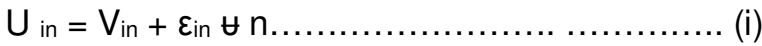

Where; $V_{\text {in }}$ is the deterministic component which can be calculated based on observed characteristics and $\varepsilon_{\text {in }}$ is the unobserved random or stochastic error component. The error component is never observed which makes it difficult to have enough information that would allow one to predict a specific individual's choice at each occasion.
Regression models can be used to make predictions about the patterns of choices over many individuals and many choice occasions. The probability of a decision maker $i$ choosing alternative $k$ among $n$ alternatives is expressed as follows;

$\mathrm{P}_{\mathrm{ik}}=\operatorname{Pr}\left(\mathrm{U}_{\mathrm{in}}>\mathrm{U}_{\mathrm{ik}} \forall \mathrm{n} \neq \mathrm{k}\right.$

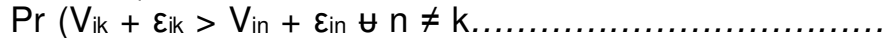

(ii)

The utility specified above under a random utility modeling framework can be extended as follows:

$V_{i k}+\varepsilon_{i k}=\lambda_{i k} \beta+\varepsilon_{i k}$

(iii)

Where; $\lambda$ is a vector of characteristics which influence the choice of a livelihood strategy, $\beta$ is the coefficient vector and as stated earlier $\varepsilon_{i k}$ is the term for random disturbances with an extreme value distribution. The estimation of equation (ii) is based on the assumption that each of the random components "in" in the utilities is distributed independently.

\section{CONCEPTUAL FRAMEWORK}

The conceptual framework in Figure 1 outlines the conceptualized interrelationships in the study, the key variables involved and how they were interrelated. The reasoning was that, some households choose to shift to agro-pastoralism while others choose not. The decision to shift to agro-pastoralism was assumed to be determined by a number of factors: household factors (education, age, gender, household size), financial (offfarm income, crop and livestock incomes) physical and institutional factors (distance to watering points, distance to market, crop and livestock diversity, land tenure, farmer trainings and extension services, credit access and group membership).

For example, gender of household head may influence the ability of the household to own assets such as livestock and power to make major decisions regarding agricultural production. So, depending on who makes decisions, a household can decide to remain pastoral or become agro-pastoral. Off-farm income enunciates the choice and ability to shift to agropastoralism, but the decision whether to shift or not lies within an individual. Group involvement ensures accessibility to credit, equipment and collective marketing which is more effective than individual marketing, thus depending on whether a household belongs to a group or not will determine his/her decision to shift to agro-pastoralism. Land tenure also could influence the shift given that households with private land ownership tenure system can easily prove direct ownership unlike communal land ownership, for which there is no direct claim to land by the individual households. Finally, the decision made (to shift to agro- 
pastoralism or not) determines household livelihoods. These livelihoods (pastoralism and agro-pastoralism) are associated with trade-offs in terms of socio-economic characteristics, economic benefits, and crop and livestock enterprise diversities. However, the study sought to evaluate crop and livestock enterprise diversities.

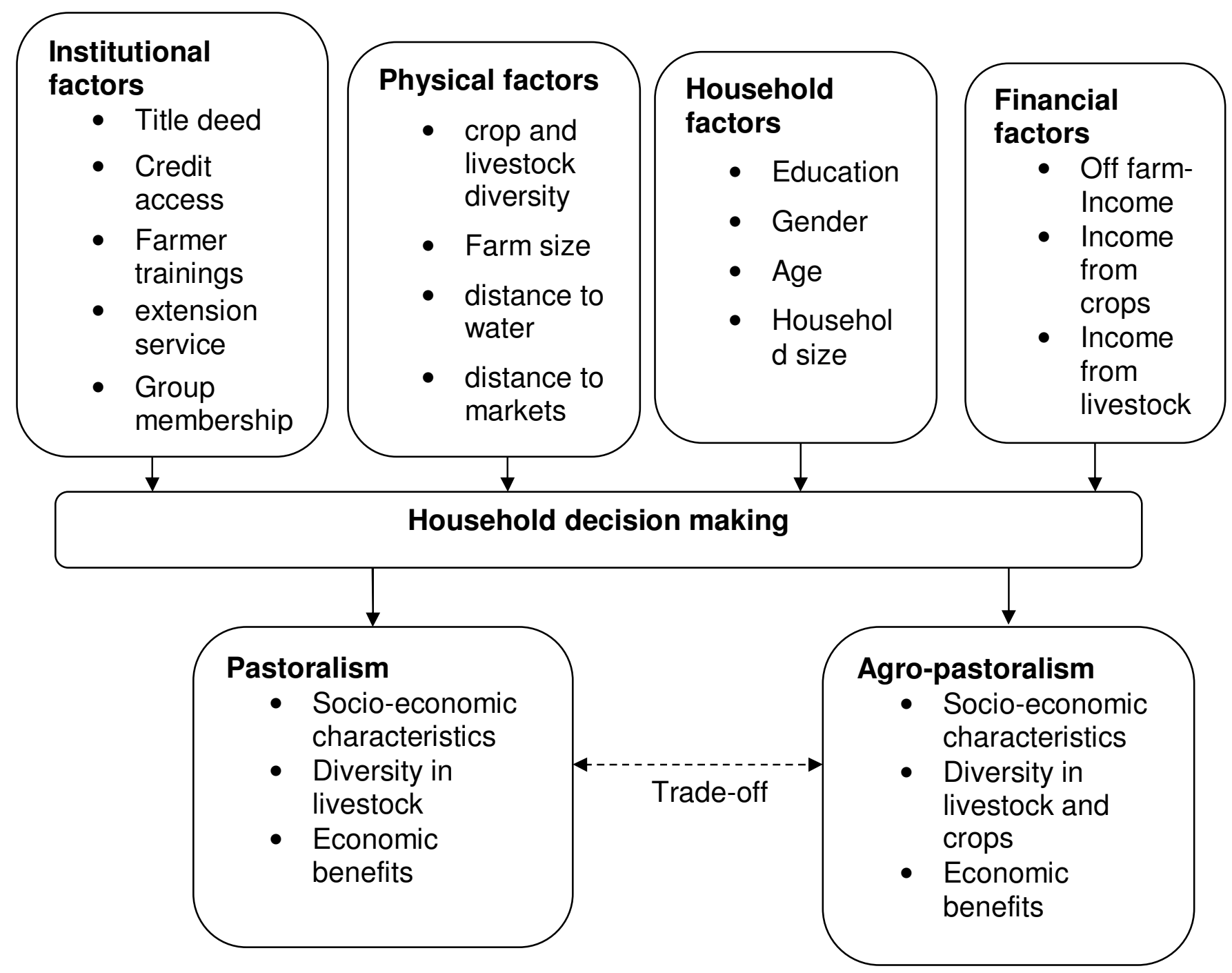

Figure 1: Conceptual framework

Source: Own conceptualization (2012)

\section{MATERIALS AND METHODS}

\section{Study area}

The study was conducted in TransMara West District of Narok County, Kenya between June and August, 2011. The district lies on the south-western part of Rift Valley Province between Latitude $0^{\circ} 50^{\prime}$ and $1^{\circ} 50^{\prime}$ 'South and Longitude $34^{\circ} 35^{\prime}$ and $35^{\circ} 14^{\prime}$. The topography of TransMara West district comprises three major categories: the highlands which lie between $2,200 \mathrm{~m}$ and $2,500 \mathrm{~m}$ above sea level, the plateau which rises from 1524 to $2200 \mathrm{~m}$ above sea level and the lowland which lie below $1524 \mathrm{~m}$ above sea level. The lowland receives $1000 \mathrm{~mm}$ of rainfall per year.
The district has seven divisions covering an area of about 2,846.40 square kilometers with an estimated population of 170,591 (1999 census), growing at a rate of $2.23 \%$ and has a population density of 60 people per square Kilometer (MOFAP, 1999) with an estimated poverty index of about $40 \%$ (MOFAP, 1999). The study area is estimated to have 14517 households (in the eight locations of interest) with an average household size of 5 people (MOFAP, 1999). Settlement patterns in the district correspond to land use, land tenure and urbanization. Settlement is sparse where large stocks of livestock are reared, but comparatively denser in areas where crop farming is practiced and small stocks of livestock reared. 


\section{Sample Size}

The needed sample size was calculated from the approach of Anderson et al. (2007):

$$
n=\frac{\left.\left(Z_{\alpha}\right)_{2}\right)^{2} p^{*} q}{E^{2}}
$$

Where;

$\mathrm{n}=$ Sample size

$Z=$ confidence level (95\% in this case)

$\mathrm{z}_{\alpha / 2}=1.96$

$\mathrm{P}^{*}=$ proportion of the population

$q=1-p^{*}$

$\mathrm{E}=$ allowable error

In computing $\mathrm{n}, \mathrm{P}^{*}=\mathrm{x} / \mathrm{N}$
Where $x$ is the population (households) involved in pastoralism and agro-pastoralism, $\mathrm{N}$ is the total population (households) in the eight locations in Kirindoni and Lolgorian divisions. From consultation with the extension service providers in the area and according to the DAO's office, $x$ was determined to be 1228 and $N$ to be 14517 (MOFAP, 1999). The proportion $\left(p^{*}\right)(x / N=1228 / 14517)$ is thus 0.08459 . With the desired margin of error $(E)$ set at 0.05 , the sample size needed was estimated at 119 from

$$
\mathrm{n}=0.08459 * 0.91541 *\left[\frac{1.96}{0.05}\right]^{2}=118.9 \approx 119
$$

An additional 11 respondents were included to cater for none and invalid responses that are common with cross sectional survey interview administration. Consequently, a sample size of 130 respondents was used.

\section{Sampling design}

The study used stratified proportionate random sampling procedure. Within TransMara district, the divisions were stratified according to agro-ecological zones. Kirindoni and Lolgorian divisions were selected because of having prominent pastoral and agro-pastoral farming households within the same agro-ecological zone. 8 locations among the two divisions were randomly selected. The locations were further stratified into two namely; pure pastoralism and a mixture of pure pastoralism and agro-pastoralism. Lastly, random selection of the respondents within the locations was made proportionate to the population of each location to obtain the required sample size. The needed proportionate sample in a location was computed from the households in a location divided by sum of all households in eight locations them multiplied by the needed sample estimate of 130 households.

\section{Data collection and requirements}

Data collection used interview schedule. Both large scale and small scale farmers were contacted. Secondary data such as the number of households in the area and the total population per location was collected from the Divisional and District Agricultural extension offices and the District development office in TransMara West district. Data requirements for analysis of livestock and crop enterprise diversities included crops and livestock assets (in numbers and types and classes) and land sizes (acreages). The livestock unit's used in the study was sourced from the District Agricultural Extension Office.

\section{Specification of the empirical model}

Chi-square and t- tests statistics were run to detect any statistical difference in diversity of crops and livestock assets between pastoral and agro-pastoral systems. Diversity was computed using Shannon index in order to account for both species dominance and evenness (Gizawa, 2006). This is unlike other indices such as Margalef index which only measures species richness. The Shannon index was used to show diversity distribution pattern to which monetary value was attached (Kaitibie et al., 2007):

$$
\text { Crop diversity (CPD) }=-\sum_{i=1}^{n} \propto_{i} \ln \propto_{i}
$$

Where: $C d \geq 0, \propto_{i}=$ area share occupied by the $i^{\text {th }}$ crop enterprise in $A_{i}$. 
Livestock diversity (LVD) $=-\sum_{i=1}^{n} \theta_{i} \ln \theta_{i}$ (v)

Where: $\theta_{i}=$ share of the Total Livestock Unit $\left(T L u_{i} / \sum_{i=1}^{n}\right.$ $\left.T L u_{i}\right), T L u \geq 0$

TLui=the total livestock unit up to the $\mathrm{i}^{\text {th }}$ livestock type. The livestock types include cows, goats, sheep, donkey and poultry.

The index ranges from 0 to 1 whereby a diversity index of 1 means high diversity whereas 0 means no diversity. The outcome of the indices was subjected to t test statistics to make inferences on crops and livestock diversity between pastoral and agropastoral systems (Anchonga et al., 2011; Donnermeyer et al., 2002; Perfecto et al., 1994).

\section{RESULTS AND DISCUSSIONS}

Figure $2 \mathrm{a}$ and $\mathrm{b}$ presents the frequencies of pastoral and agro-pastoral households compared for diversity in livestock and crops assets respectively. Chi square tests of the frequencies show dominance of poultry and goats in $(\mathrm{P}<0.05)$ agro-pastoral households while other livestock species dominated $(\mathrm{P}<0.05)$ in the pastoral households.
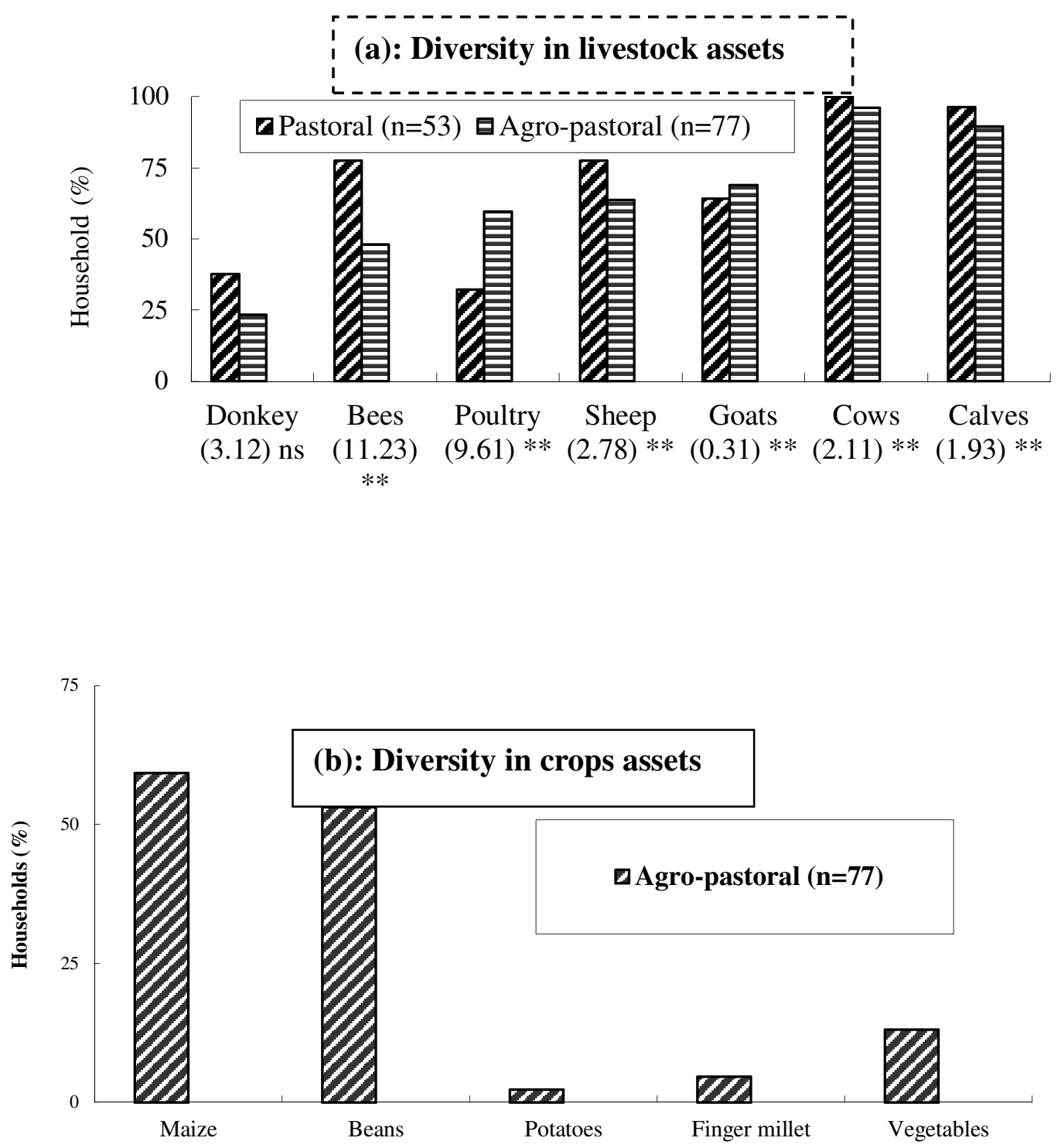

Figure 2: Frequency of pastoral and agro-pastoral households compared for diversity in livestock (a) and crops (b) assets (in brackets are Chi-Square values with ${ }^{\star *} P<0.05$, ns $\left.P>0.05\right)$. 
The result reflects that crop assets were solely associated with agro-pastoral livelihoods. Crop diversity was biased to maize and beans in over half of the households (Figure $2 \mathrm{~b}$ ) because these are food crops contributing to food self-sufficiency at the household level. Pastoralists specialized on livestock production for their livelihood assets, reflected by total exclusion of crops. The Shannon index computed for diversity of crops and livestock in pastoral and agro-pastoral farming are presented in Table 1 . The result reflects greater diversity in livestock assets in both pastoral and agropastoral farming while crop diversification is restricted to agro-pastoral farming. A Shannon index of 0 meant no diversity and was associated with specialization in farming, in this case livestock in pastoral farming. On the other hand an index of 1 meant high diversity. Livestock diversity index was not different $(P>0.01)$ between pastoral and agro-pastoral farming (0.37 verses 0.36 ). The diversity in crops among agro-pastoral farmers was (0.30), though the levels reflect less diversification, which can be attributed to preference for growing of maize and beans (Fratkin and Mearns, 2003). The results indicate that the shift from pastoral to agropastoral livelihoods has no adverse impact on livestock diversity while it promotes diversity in crops.

Table 1: Shannon index for diversity of crops and livestock in pastoral and agro-pastoral farming systems

\begin{tabular}{|c|c|c|c|c|}
\hline Variable & $\begin{array}{ll}\text { Pastoral } & \text { farming } \\
\text { system }(n=53) & \end{array}$ & $\begin{array}{l}\text { Agro-pastoral } \\
\text { system }(n=77)\end{array}$ & farming & t-test \\
\hline Livestock diversity index & $0.37 \pm 0.13$ & $0.36 \pm 0.13$ & & 0.61 \\
\hline Crop diversity index & $0.00 \pm 0.00$ & $0.30 \pm 0.08$ & & 0.00 \\
\hline
\end{tabular}

\section{CONCLUSION}

Even though no difference was exhibited between pastoral and agro-pastoral households for livestock diversity, diversity in crops was biased towards food crops of maize and beans. Enterprise diversification was high reflecting farmers attempt to achieve self-sufficiency through integration of livestock with crops production. Diversification was important so as to meet certain objectives, however, household objectives vary. Moreover, following frequent land subdivisions, land is limiting. Therefore, it would happen that households were constrained by the fact that they did not know the suitable enterprise combination which would suit their objective. Thus, there is need to improve provision of extension services and increase farmer trainings so that farmers can be sensitized on enterprise combinations which will maximize their objectives given the available resource constraints at the same time conserving the environment.

\section{ACKNOWLEDGEMENTS}

Collaborative Masters of Agricultural and Applied Economics (CMAAE) secretariat, headed by Prof. Willis Kosura, my university supervisors Dr. J.K. Lagat and Prof. B.O. Bebe, are gratefully acknowledged.

\section{REFERENCES}

Anchonga, BO, Akuja, TE, and Lagat, JK, (2011). Evaluation of the diversity of crop and livestock enterprises among agro-biodiversity farmer field schools (ABD-FFS) and Non-ABD-FFS households in Bondo District, Kenya. Journal of Applied Biosciences 38:2496-2507.

Akinwumi, JA, Jabbar, MA and Okoruwa, V, (1996). Crop-Livestock competitions in the West African derived Savanna: Application of A multi-objective programming model. Journal of Agricultural Systems 52.pp.439-453.

Anderson. D, R, Sweeny, J, D, Williams, T, A, Freeman, $\mathrm{J}$ and Shoesmith, E, (2007). Statistics for Business and Economics. Thomson Learning.

Arunga, M, Krishwa, A, Kristjanson. P, Mango, N, Omolo, A and Radeny, M, (2009). Why is it that some households fall into poverty at the same time others are escaping poverty? Evidence from Kenya. ILRI discussion paper no.16.ILRI Publication unit. Addis Ababa. Ethiopia.

Ayantunde, A, Duncan, A, Freeman, A, Herrero, M, Sere, C, Tarawali, S and Wright, I, (2008). Livestock production and poverty alleviation, challenges and opportunities in Arid and semi-arid tropical rang land based systems. ILRI, Nairobi, Kenya.

Binsbergen, JV and Watson, DJ, (2008). Livelihood diversification opportunities for Pastoralists in Turkana. ILRI Research report 5. Nairobi, Kenya. 
Cavatassi, R, Lipper, L, and winters, P, (2006). Sowing the seeds of social relations, the role of social capital in crop diversity. Agricultural and development economics division of the food and agriculture organization of the United Nations (FAO - ESA). Working Paper number 06-16.

Coast, E, Homewood, K, Kariuki, A, Kikula, I, Kivelia, J, Lambin, EF, Said, M, Serneels, S, and Thompson, M, (2001). Long term changes in Serengeti -Mara wildebeest and land cover: Pastoralism, polulation or policies? ILRI publications. ILRI. Nairobi, Kenya.

Coast, E, Homewood, K, Kiruswa, S, Serneels, S, Trench, $P$ and Thompson, M, (2006). Maasai pastoralists; Diversification and poverty. London. LSE Research online. (Online Access on 23/2/2010).

COMESA (2009). Income diversification among pastoralists: Lessons for policy makers. Policy brief No. 3, 2009. (Online access on 5/3/2010)

Donnermeyer, J, Erbaugh, JM, Kibwika, PK and Yamanywa, S, (2002) "Assessment of the integrated pest management collaborative research support project's (IPM CRSP) activities in Uganda: Impact on farmers awareness and knowledge of IPM skills. Journal of African Crop Science, 10(3):271-280.

Fratkin, E and Mearns, R, (2003).Sustainability and Pastoral Livelihoods: Lessons for East African Maasai and Mongolia. Human Organ. 62(2): 2003.

Freeman, A, Herrero, M, Mwai, O and Thornton, P, (2007). Vulnerability, climate change and livestockResearch opportunities and challenges for poverty alleviation. An open Access Journal published by ICRISAT. 4 Issue 1.

Freeman, HA, Kaitibie, S, Moyo, S and Perry, BD, (2008). Livestock, livelihoods and vulnerability in Lesotho, Malawi and Zambia: Designing livestock interventions for emergence situations. ILRI, Research report 8.ILRI, Nairobi, Kenya.

FSM Itd. (2010). Sustainable mechanization for unlocking the pastoralist economic potential unveiled. Nairobi, Kenya. www.finelinesml.com.pdfs (Online access on 20/2/2010)

Galvin, KA, (1992). Nutritional ecology of pastoralists in dry tropical Africa. American Journal of Human Biology 4.pp. 209-221.

Galvin, KA, (2009). Transitions: Pastoralists living with change. Annual Review of Anthropology 2009. 38; 185-198.

Gerber, F, Herrero, M, Reid, RS and Thornton, PK, (2009). Livestock, livelihoods and the Environment: Understanding the Trade-offs. Journal of Current Opinion of Environmental Sustainability.1:111-120.

Gizawa, AW, (2006). Population status and socioeconomic importance to gum and resin bearing species in Borana lowlands, Southern Ethiopia. Msc. thesis submitted to the school of graduate studies, Addis Ababa University, department of Biology Ethiopia.

Griffiths, SMN, (2007). How many wildebeest do you need? Journal of World Economics 8 (2), $41-64$.
Gumbo, D and Maitima, JM, (2007). Land Use changes in Sub-Saharan. Book Chapter In: Luanne Otter (ed.) Global Climatic Changes and their impacts on Africa, a synthesis perspective IGBP START Publication. East African educational Publishers. Pgs 116 - 140. ILRI, Nairobi, Kenya.

Herrero, M, Kristjanson, P, Nkedianye, D and Radeny, M, (2006). Livelihood choices and returns among agro-pastoralists in Southern Kenya. ILRI. Nairobi, Kenya.

Homewood, K, Kristjanson, P and Trench, PC, (2009). Staying Maasai? Pastoral livelihoods, diversification and the role of wildlife in development. Journal of Human Ecology and Adaptation. 5 pp.369-408

Kaitibie, S, Kariuki, P, Liyama, M and Morimoto $\mathrm{Y}$, (2007). The status of crop livestock system and evolution toward integration. Annals of Arid Zone, 46.pp.1-23.

Lesorogol, CK, (2008). Privatizing pastoral lands: Economic and normative outcomes in Kenya. Journal of World Development. 33 No.11.pp.19591978.

Mochabo, MOK, Murilla, GA, Nyamwaro, SO and Wanjala, KB, (2006). Conflict minimizing strategies on natural resource management and use: The case for managing and coping with conflict between wildlife and agro-pastoral production resources in TransMara district, Kenya. Policy Research conference on pastoralism and poverty reduction in East Africa, Nairobi. Kenya.

MOFAP (1999). 1999 Population and housing census. Counting our people for development. Volume 1.CBS.Nairobi, Kenya.

Morton J and Meadows N, (2000). Pastoralism and sustainable livelihoods: an emerging agenda. University of Greenwich.

Mwangi, E, (2005). The Transformation of Property Rights in Kenya's Maasai land: Triggers and Motivations. IFPRI. Washington D.C, U.S.A

Mwang'ombe, AW, Nyariki, DM and Thompson, DM, (2009). Land use change and livestock production challenges in an integrated system: The Maasai mara ecosystem, Kenya. Journal of Human Ecology 26 (3):163-173

Perfecto I, Rathcke, B and Roth, DS, (1994). "The effects of management systems on ground-foraging Ant diversity in Costa Rica". Ecological Applications 4(3):423-436 .

Simtowe, F.P. (2009). Livelihood diversification and gender in Malawi. Journal of Agricultural Research 5 (3).pp 204-216

Tangus, JK, (2004). Influence of enterprise diversification on risk management amongst Samburu pastoralists of Kenya. Msc. thesis presented to graduate School of Egerton University. Department of natural resource management. Egerton University, Kenya.

WIBD (2005). Participatory research and social analysis with special emphasis to gender in pastoral communities of Ethiopia. Addis Ababa. Ethiopia. 
WISP (2008). Forgotten Services, diminished goods:

www.iucn.org/wisp/wisp-publications.html (Accessed Understanding the agro ecosystem of pastoralism.

WISP Policy Note No.8. IUCN. Nairobi, Kenya. on $1 / 2 / 2010)$

Cite this Article: Magembe EM, Bebe BO, Lagat JK, 2014. Evaluation of Livestock- Crop Enterprise Diversity Associated with Shift from Pastoral to Agro-Pastoral Farming Systems in Transmara West District of Narok County- Kenya. Greener Journal of Agricultural Sciences. 4(3):101-109, http://dx.doi.org/10.15580/GJAS.2014.3.020514093. 